\title{
Antiplatelet Therapy in Cardiovascular Disease - Past, Present and Future
}

\author{
Mariano E. Brizzio \\ The Valley Heart and Vascular Institute, Ridgewood, New Jersey \\ USA
}

\section{Introduction}

Platelet activity has a very important role in the pathogenesis of atherosclerosis disease. In addition to being part of the coagulation system, they contribute to all phases of the atherosclerosis process (1) The "intervention" in the platelet activity has been played a central role in the treatment of coronary artery disease (CAD) (2).

Aspirin is considered the foundation antiplatelet therapy for patients at risk of cardiovascular events. However, in the last few decades many different agents were introduced to have a more effective antiplatelet action and improve treatment outcomes in coronary syndromes.

In this chapter you will find a systematic review of all the antiplatelet agents available: mechanism of action, pharmacokinetics, side effects, evidence of effectiveness and their use in clinical settings. A special emphasizes will point out agents that are in investigational stage and what are the future perspectives.

\subsection{Platelet mechanisms of action}

Platelets play a critical role in the normal coagulation system by "preventing" bleeding after blood vessels are damaged. In addition they contribute to different phases of the atherosclerotic process (1). Rupture of a previously formed atherosclerotic plaque exposes collagen, smoothmuscle cells and von Willebrand factor (vWF) all of which trigger platelet activation and massive aggregation (3). The result of this accumulation of platelets is thrombosis. Acute coronary syndrome (ACS) is a consequence of the occlusion of an atherosclerotic vessel by the thrombotic process. As described before, collagen and vWF in addition to thromboxane A2 (TXa2), thrombin and adenosine diphosphate (ADP) are the most powerful platelet activators (4). When a platelet is activated a conformational change occurs in a receptor located in the platelet membrane called glycoprotein IIb/IIIa which promotes platelet aggregation (5).

Antiplatelet agents that target critical steps of the thrombotic mechanism described above have been developed in the last three decades. However, treatment with these agents can sometimes increase the risk of "undesirable" bleeding complications (6).

\section{The traditional anti-platelet agents}

Many anti-platelet agents have been tested and used as an effective treatment in arterial thrombosis. Acetyl salicylic acid, commonly known as aspirin was the first anti-platelet 
agent used and proven to be effective to reduce the incidence of myocardial infarction and stroke in many high risk vascular patients (2).The recurrence of vascular events in patients treated with aspirin alone ranges between $10-20 \%$ within five years of the initial event (2-7).

Aspirin is effective by blocking the synthesis of TXa2, a powerful platelet activator.

In the last decade, the thienopyridines such as clopidogrel have been used to improve outcomes in the treatment of ACS. This anti-platelet agent irreversibly blocks the P2Y12 receptor, precluding the platelet activation by ADP (2). Its anti-platelet mechanism of action clearly differs from aspirin. In the majority of cardiovascular patients the combination of clopidogrel and aspirin has additive beneficial effects when compared with clopidogrel or aspirin alone (8). Clopidogrel also has some limitations, which have prompted the development of newer anti-platelet agents which interact at different sites of the coagulation cascade.

The following figure reflects the site of action of the common antiplatelet agents (figure 1)

\section{The thromboxane A2 antagonist}

Dipyridamole (Persantine) acts as a thromboxane synthase inhibitor, therefore lowering the levels of TXA2 and thus stops the effects of TXA2 as a platelet activator (9).

Also can causes systemic vasodilation when given at high doses over a short period of time. The latter, due to the inhibition of the cellular reuptake of adenosine into platelets, red blood cells and endothelial cells leading to increased extracellular concentrations of adenosine (9). It also inhibits the enzyme adenosine deaminase, which normally breaks down adenosine into inosine. This inhibition leads to further increased levels of extracellular adenosine, producing a strong vasodilatation (9).

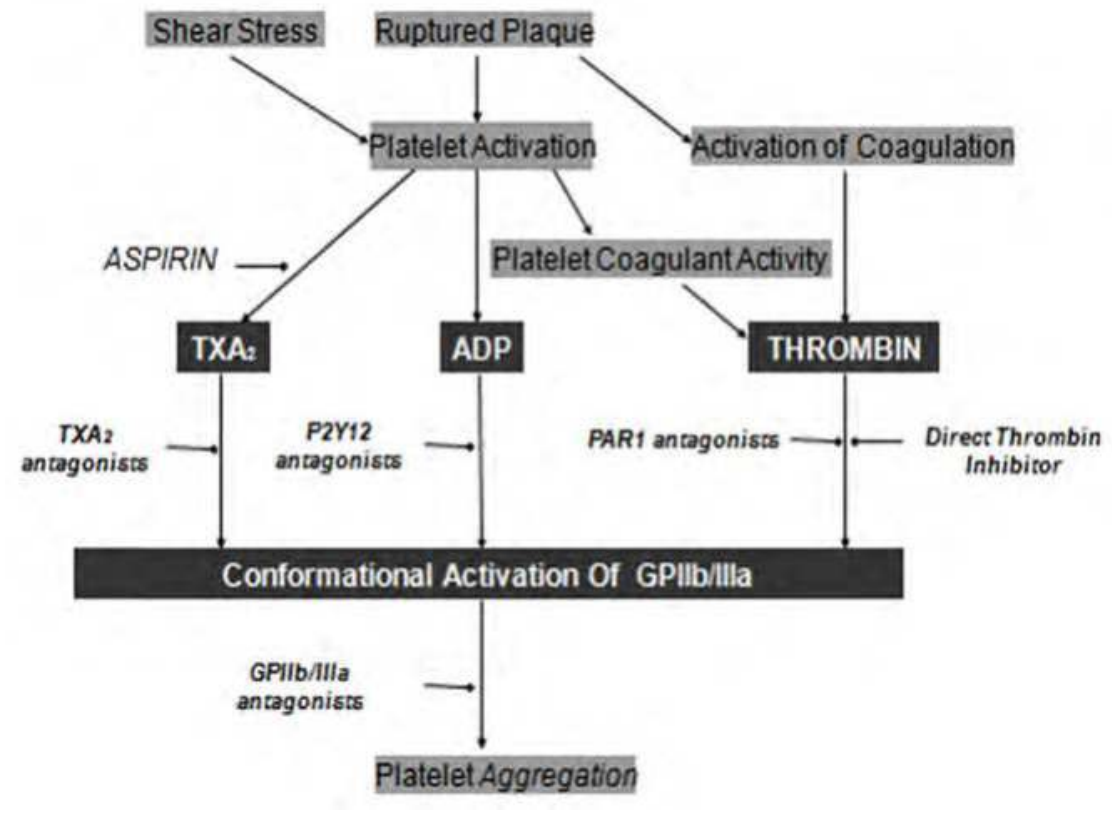




\begin{tabular}{|l|}
\hline \multicolumn{1}{|c|}{ Antiplatelet agents nowadays } \\
\hline Inhibits the synthesis of TXa2 \\
Aspirin \\
TXa2 antagonist \\
Dipyridamole \\
Terutroban \\
P2Y $\mathbf{1 2}$ antagonist \\
Ticlopidine \\
Clopidogrel \\
Prasugrel \\
Ticagrelor \\
Cangrelor \\
Glycoprotein IIb/IIIa antagonist \\
Abciximab \\
Tirobiban \\
Eptifibatide \\
Protease-activated receptor 1 antagonist \\
Vorapaxar \\
Direct thrombin Inhibitor \\
Bivalirudin
\end{tabular}

Modified release dipyridamole is used in conjunction with aspirin (under the trade names Aggrenox in the USA or Asasantin Retard in the UK) in the secondary prevention of stroke and transient ischemic attack. This practice has been confirmed by the ESPRIT trial (9). A triple therapy of aspirin, clopidogrel and dipyridamole has been investigated, but this combination led to an increase in adverse bleeding events (10).

Via the mechanisms mentioned above, when given as 3 to 5 min infusion it rapidly increases the local concentration of adenosine in the coronary circulation which causes vasodilation. Vasodilation occurs in healthy arteries, whereas stenosed arteries remain narrowed. This creates a "steal" phenomenon where the coronary blood supply will increase to the dilated healthy vessels compared to the stenosed arteries which can then be detected by clinical symptoms of chest pain, electrocardiogram and echocardiography when it causes ischemia. Flow heterogeneity (a necessary precursor to ischemia) can be detected with gamma cameras and SPECT using nuclear imaging agents such as Thallium-201 and Tc99m-Sestamibi (9).

Terutroban is a selective antagonist of the thromboxane receptor. It blocks thromboxane induced platelet aggregation and vasoconstriction (11). As of 2010, it is being tested for the secondary prevention of acute thrombotic complications in the Phase III clinical trial. However, the recent publication of the finalized trial PERFORMS shown no clinical advantage in comparison with patients with aspirin monotherapy in preventing strokes (12). At the time of this publication its use in clinical practice is not approved in the USA.

\section{Other P2Y 12 antagonist}

Ticlopidine an anti-platelet drug in the thienopyridine family inhibits platelet aggregation by altering the function of platelet membranes by irreversibly blocking ADP receptors. This 
prevents the conformational change of glycoprotein IIb/IIIa which allows platelet binding to fibrinogen (13). It is used in patients in whom aspirin is not tolerated, or in whom dual anti-platelet therapy is desirable (in combination with Aspirin). Because it has been reported to increase the risk of thrombotic thrombocytopenic purpura (TTP) and neutropenia, its use has largely been supplanted by the newer drug, clopidogrel, which is felt to have a much lower hematologic risk (14).

Prasugrel, a novel thienopyryridine was approved for clinical use in the USA by the Food and Drug Administration (FDA) in 2010. Unlike clopidogrel, which undergoes a two-step, CYP450-dependent conversion to its active metabolite, prasugrel only requires single-step activation. Prasugrel is a more potent platelet inhibitor with faster action and inhibition. Also, it has been estimated that due to its "easy metabolism" its genetic resistance is less likely (15). In other words, prasugrel has a significantly lower incidence of hyporesponsiveness in comparison with clopidogrel (15). However, the risks of bleeding in these patients are greater than clopidogrel (16).

Ticagrelor is the most novel class of anti-platelet drugs, the cyclopentytriazolopyrimides, which also inhibit the P2Y12 receptor as the thienopyryridines. However, it has a simpler and faster metabolism (rapid onset of action) high potency and most importantly reversibility (17). The latter, makes this drug safer in regards of bleeding complications.

Cangrelor, an ATP analog, is an investigational intravenous anti-platelet drug. This agent has biphasic elimination and possesses the advantages of high potency, very fast onset of action and very fast reversibility after the discontinuation (16).This gives a considerable advantage over other ADP antagonist in patients who might need immediate surgery. However, after initial treatment, patients who received intravenous infusion of Cangrelor often require continued treatment with one of the oral P2Y12 antagonists, something that one must take into consideration (16).

\section{Glycoproteins Ilb/lla antagonist}

Abciximab, more known as the ReoPro is an antibody against glycoprotein IIb/IIIa receptor. It had a lot of popularity within interventional cardiologist 10 years ago. It is barely used today. It was replaced by newer IV agents. Abciximab has a plasma half-life of about ten minutes, with a second phase half-life of about 30 minutes. However, its effects on platelet function can be seen for up to 48 hours after the infusion has been terminated, and low levels of glycoprotein $\mathrm{IIb} / \mathrm{III}$ a receptor blockade are present for up to 15 days after the infusion is terminated (18).

Tirobiban (Aggrastat) is a synthetic, non-peptide inhibitor acting at glycoprotein (GP) IIb/IIIa receptors. It has a rapid onset and short duration of action after proper intravenous administration. Platelet activity returns to normal 4 to 8 hours after the drug is withdrawn (19). Eptifibatide (Integrilin) is the newer anti-platelet drug which inhibits the glycoprotein IIb/IIIa inhibitor. It belongs to the class of the so-called arginin-glycin-aspartat-mimetics and reversibly binds to platelets. Eptifibatide has a short half-life, 3 to 5 hours after the discontinuation platelet activity recovers to normal levels (20).The drug is the third inhibitor of $\mathrm{GPIIb} / \mathrm{III}$ that has found broad acceptance within interventional cardiologists nowadays.

\section{Proteasa-activated receptors antagonist}

Vorapaxar (formerly SCH 530348) is a thrombin receptor (PAR-1) antagonist based on the natural product himbacine. It is an experimental pharmaceutical treatment for acute coronary syndrome as a very powerful platelet inhibitor (21).In January 2011, the clinical trial was 
halted for patients with stroke and mild heart conditions due to safety reasons. It is unknown if it will continue.

\section{Direct thrombin inhibitors}

Bivalirudin (Angiomax) is a specific and reversible intravenous direct thrombin inhibitor. Clinical studies demonstrated consistent positive outcomes in patients with stable angina, unstable angina (UA), non-ST segment elevation myocardial infarction (NSTEMI), and STsegment elevation myocardial infarction (STEMI) undergoing PCI in 7 major randomized trials (22). Coagulation times and platelet activity return to baseline approximately 1-6 hour following cessation of bivalirudin administration (23).

\section{Conclusions}

Antiplatelet therapy plays a crucial role in the treatment of coronary patients. The continuous introduction of new agents is geared to improve results in patient ongoing percutaneous coronary interventions. However, the side effects of theses should be monitored closely. In the end, the ideal management of patients with acute coronary syndrome should be to be a collaborative effort between cardiologist and surgeons to assure the best outcomes possible.

\section{References}

[1] Hoffman M et al.Activated factor VII activates Factor IX on the surfaces of activated platelets. Blood Coag Fibrinolyis. 1998:9; 61-65.

[2] Antithrombotic triallist's collaboration. Collaborative meta-analysis of randomized trials of antiplatelet therapy for prevention of death, myocardial infartion, and stroke in high risk patients. BMJ 2002;324:71-86

[3] Heemskerk JW. Funtion of glycoprotein VI and intgrelin in the procoagulant response of single, collagen-adherent platelets. Throm Hemost 1999;81:782-792

[4] Jin, J, Kunapuli, SP. Coactivation of two different G protein-coupled receptors is essential for ADP-induced platelet aggregation. Proc Natl Acad Sci USA 1998;95:8070-74

[5] Heechler B, et al. The P2Y1 receptor in necessary for adenosine 5'-diphodphate-induced platelet aggregation. Blood 1998;92:152-159

[6] Brizzio, ME, Shaw, RE, Bosticco B, et al. Use of an Objective Tool to Assess Platelet Inhibition Prior to Off-Pump Coronary Surgery to Reduce Blood Usage and Cost. Journ Interv Cardiol. 2011 In press

[7] de Werf F et al. Dual antiplatelet therapy in high-risk patients. Euro Heart J . 2007:9:D3D9 MC,

[8] Metha SR, Peters RJG, Bertrand ME, et al., for the Clopidrogel in Unstable angina to prevent Recurrent events (CURE) Trial Investigators. Effects of pretreatment with clopidogrel and aspirin followed by long-term therapy in patients undergoing percutaneous coronary intervention: the PCI-Cure study. Lancet 2001;358:527-33.

[9] Halkes PH, van Gijn J, Kappelle LJ, Koudstaal PJ, Algra A (May 2006). "Aspirin plus dipyridamole versus aspirin alone after cerebral ischaemia of arterial origin (ESPRIT): randomised controlled trial". Lancet.2006; 367: 1665-73.

[10] Sprigg N, Gray LJ, England T, et al. (2008). Berger, Jeffrey S.. ed. "A randomised controlled trial of triple antiplatelet therapy (aspirin, clopidogrel and 
dipyridamole) in the secondary prevention of stroke: safety, tolerability and feasibility". PLoS One. 2008 Aug 6;3(8):e2852

[11] Sorbera LA, Serradel N, Bolos J, Bayes M. Terutroban sodium.Drugs of the Future 2006;31 (10):867-873.

[12] Hennerici, M. G.; Bots, M. L.; Ford, I.; Laurent, S.; Touboul, P. J. "Rationale, design and population baseline characteristics of the PERFORM Vascular Project: an ancillary study of the Prevention of cerebrovascular and cardiovascular Events of ischemic origin with teRutroban in patients with a history oF ischemic strOke or tRansient ischeMic attack (PERFORM) trial". Cardiovascular Drugs and Therapy 2010; 24 (2): 175.

[13] Berger PB. Results of the Ticlid or Plavix Post-Stents (TOPPS) trial: do they justify the switch from ticlopidine to clopidogrel after coronary stent placement? Curr Control Trials Cardiovasc Med. 2000; 1(2): 83-87.

[14] Bennet CL, Davidson CJ, Raisch DW, et al. Thrombotic Thombocytopenic purpura with ticlopidine in the setting of coronary artery stents and stroke prevention. Arch Intern Med. 1999;159:2524-2528.

[15] Wiviott $S$ et al. Prasugrel versus clopidogrel in patient with acute coronary syndromes. N Engl J Med 2008;357:2001-2015

[16] Raju NC, Eikelboom, Hirsh J. Platelet ADP-receptor antagonist for cardiovascular disease:past, present and future. Nature Cini Pract 2008;5(12):766-779

[17] Wallentin, Lars; Becker, RC; Budaj, A; Cannon, CP; Emanuelsson, H; Held, C; Horrow, $\mathrm{J}$; Husted, $\mathrm{S}$ et al. Ticagrelor versus Clopidogrel in Patients with Acute Coronary Syndromes". N Engl J Med 2009;361 (11): 1045-57.

[18] Tcheng, JE; Kandzari, DE; Grines, CL; Cox, DA; Effron, MB; Garcia, E; Griffin, JJ; Guagliumi, $\mathrm{G}$ et al. "Benefits and risks of abciximab use in primary angioplasty for acute myocardial infarction: the Controlled Abciximab and Device Investigation to Lower Late Angioplasty Complications (CADILLAC) trial." Circulation 2003;108 (11): 1316-23

[19] Shanmugam G. Tirofiban and emergency coronary surgery. Eur J Cardiothorac Surg 2005;28:546-550

[20] Mann H, London AJ, MannJ. Equipoise in the Enhanced Supression of the Platelet IIb/IIIa Receptor with Integrilin Trial (ESPRIT): a critical appraisal. Clin Trials June 2005 vol. 2 no. $3233-243$

[21] Chackalamannil S . "Discovery of a Novel, Orally Active Himbacine-Based Thrombin Receptor Antagonist (SCH 530348) with Potent Antiplatelet Activity". J of Medic Chemis 200851 (11):3061-04

[22] Kushner FG, Hand M, Smith SC Jr, et al. 2009 Focused Updates: ACC/AHA Guidelines for the Management of Patients With ST-Elevation Myocardial Infarction (Updating the 2004 Guideline and 2007 Focused Update) and ACC/AHA/SCAI Guidelines on Percutaneous Coronary Intervention (Updating the 2005 Guideline and 2007 Focused Update): a Report of the American College of Cardiology Foundation/American Heart Association Task Force on Practice Guidelines. J Am Coll Cardiol. 2009 Nov 18.

[23] Stone GW, McLaurin BT, Cox DA, et al.; for the ACUITY Investigators. Bivalirudin for patients with acute coronary syndromes. N Engl J Med. 2006;355:2203-2216. 


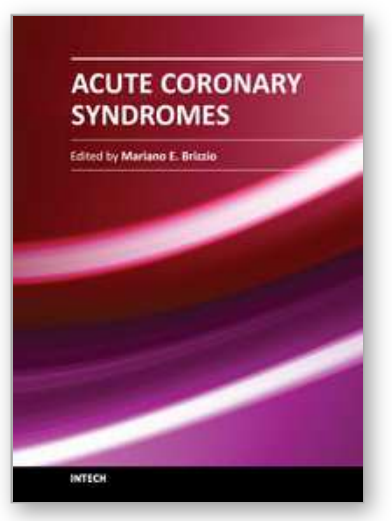

\author{
Acute Coronary Syndromes \\ Edited by Dr. Mariano Brizzio
}

ISBN 978-953-307-827-4

Hard cover, 214 pages

Publisher InTech

Published online 24, February, 2012

Published in print edition February, 2012

This book has been written with the intention of providing an up-to-the minute review of acute coronary syndromes. Atherosclerotic coronary disease is still a leading cause of death within developed countries and not surprisingly, is significantly rising in others. Over the past decade the treatment of these syndromes has changed dramatically. The introduction of novel therapies has impacted the outcomes and surviving rates in such a way that the medical community need to be up to date almost on a "daily bases". It is hoped that this book will provide a timely update on acute coronary syndromes and prove to be an invaluable resource for practitioners seeking new and innovative ways to deliver the best possible care to their patients.

\title{
How to reference
}

In order to correctly reference this scholarly work, feel free to copy and paste the following:

Mariano E. Brizzio (2012). Antiplatelet Therapy in Cardiovascular Disease - Past, Present and Future, Acute Coronary Syndromes, Dr. Mariano Brizzio (Ed.), ISBN: 978-953-307-827-4, InTech, Available from: http://www.intechopen.com/books/acute-coronary-syndromes/antiplatelet-therapy-in-cardiovascular-diseasepast-present-and-future-

\section{INTECH}

open science | open minds

\section{InTech Europe}

University Campus STeP Ri

Slavka Krautzeka 83/A

51000 Rijeka, Croatia

Phone: +385 (51) 770447

Fax: +385 (51) 686166

www.intechopen.com

\section{InTech China}

Unit 405, Office Block, Hotel Equatorial Shanghai

No.65, Yan An Road (West), Shanghai, 200040, China 中国上海市延安西路65号上海国际贵都大饭店办公楼 405 单元

Phone: +86-21-62489820

Fax: $+86-21-62489821$ 
(C) 2012 The Author(s). Licensee IntechOpen. This is an open access article distributed under the terms of the Creative Commons Attribution 3.0 License, which permits unrestricted use, distribution, and reproduction in any medium, provided the original work is properly cited. 